\title{
Geochemistry and petrogenesis of Upper Cretaceous basaltic rocks from southern Malagasy
}

\author{
J. Dostal ${ }^{\mathrm{a}}$, C. Dupuy ${ }^{\mathrm{b}}$, C. Nicollet ${ }^{\mathrm{c}}$ and J.M. Cantagrel ${ }^{\mathrm{c}}$ \\ aDepartment of Geology, Saint Mary's University, Halifax, N.S. B3H 3C3. Canada \\ "Centre Géologique et Géophysique, Université des Sciences et Techniques du Languedoc, F-34060 Montpellier C'edex. France" \\ 'Laboratoire de Géologie. Université de Clermont-Ferrand, 5 rue Kessler. F-63018 Clermont-Ferrand Cedex, France
}

(Received June 13, 1989; revised and accepted October 23, 1991)

\begin{abstract}
Dostal, J., Dupuy, C., Nicollet, C. and Cantagrel, J.M., 1992. Geochemistry and petrogenesis of Upper Cretaceous basaltic rocks from southern Malagasy. Chem. Geol., 97: 199-218.

Upper Cretaceous basaltic rocks of southern Malagasy consist of tholeiitic flows and dykes and alkali basaltic dykes. Coninental tholeiites include relatively primitive lava types with $\mathrm{Mg}$-numbers $\sim 0.6-0.5$ and voluminous evolved basaltic lavas and dykes with $\mathrm{Mg}$-number $\sim 0.4$. The evolved tholeiites have compositions similar to the high-Ti (or enriched) basalts from the Karoo and Paraná flood basalt provinces. They are characterized by a high content of strongly and moderately incompatible trace elements and a relative depletion of $\mathrm{Nb}$ and $\mathrm{Sr}$. The evolved tholeiites were probably derived from subcontinental lithosphere. The primitive tholeiites resemble enriched MORB and are not directly related to the evolved types. Alkali basalts ( $1-15 \%$ normative nepheline) possess compositional characteristics of oceanic island basalts and show some geochemical similarities to the primitive tholeiites. Both rock-types were probably derived from a mantle plume. The upwelling piume induced lithospheric melting which produced the parental magmas of the evolved tholeiites. The Mesozoic volcanism of Malagasy displays many similarities to other flood basalt provinces including its large volume, rock composition and emplacement near plate margins.
\end{abstract}

\section{Introduction}

The Mesozoic evolution of Malagasy is important for understanding and reconstructing the post-Gondwanaland history and for refining plate-tectonic models for the Indian Ocean. After the break-up of Gondwanaland during the period of $130-80 \mathrm{Ma}$ ago, Malagasy was probably a part of the Indian plate. Sea-floor spreading took place between the African and Indian plates. About $80 \mathrm{Ma}$ ago, the spreading axis moved into a new position between India and Malagasy leading to the separation of Malagasy from India. The rifting stopped $\sim 64 \mathrm{Ma}$ ago and shifted northwards triggering the opening of the Arabian Sea (Courtillot et al., 1986). The new rift was located between India and the Seychelles Islands, northeast of Malagasy.

The voluminous Mesozoic flood basalt volcanism in Malagasy has been related to the Marion-Prince Edward hot spot currently located southeast of South Africa (R.A. Duncan, 1981; Hartnady and Le Roex, 1985). The predicted path of this hot spot is subparallel to the lineaments produced by the St. Helena and Tristan da Cunha hot spots (Atlantic Ocean) and coincides fairly well with the Malagasy Ridge. Continental flood basalts which are widespread in Malagasy constitute a significant part of the Mesozoic stratigraphic column. However, very little is known about their age, composition and origin. The purpose of this paper is to geochemically characterize the 
continental basalts of southern Malagasy and put constraints on their genesis. In addition, we present $\mathrm{K} / \mathrm{Ar}$ data on the basalts. The ages of the Malagasy basalts are important for the refinement of the hot spot model and the reconstruction of the motions of the major tectonic plates. The upper Cretaceous volcanism of Malagasy provides an important temporal connection between major flood basalt events - Lower Jurassic Karoo and Lower Cretaceous Etendeka of southern Africa and Cretaceous/Tertiary Deccan of India - which are associated with the gradual break-up of Gondwanaland.

\section{Geological and petrographic notes}

Upper Cretaceous basaltic volcanism is widespread around the coast of Malagasy. In the southwestern part of the island (Fig. 1), the basaltic rocks occur predominantly as lava flows although locally some sills are present. Scarce rhyolitic dykes cross-cut the basaltic sequence. The lava flows, which mainly lie on top of Jurassic and Cretaceous sediments, crop out over an area $>200 \mathrm{~km}$ long and $2-10 \mathrm{~km}$ wide. Drill holes suggest an extension of the volcanic field farther westward toward the coast as well as to the south and probably even to a submarine plateau. Along the southeastern coast, the volcanic belt extends for a distance of $>500$ km (Fig. 1). In the southeastern and southernmost part of the island, including the volcanic/subvolcanic complex of Androy, the volcanics were directly emplaced on the Precambrian basement (Nicollet, 1984). There, the volcanic sequence, composed of intercalated basaltic and subordinate rhyolitic and dacitic lava flows, is $\sim 500 \mathrm{~m}$ thick although locally the thickness reaches $3000 \mathrm{~m}$ in the Androy massif (Battistini, 1959). Several gabbro-syenite intrusive complexes, which appear to be associated with the Cretaceous volcanism, occur or may be inferred from the gravity anomalies in southern Malagasy (Rechenmann, 1982).
The basaltic rocks also form numerous dykes $\left(>500\right.$ ) with a general $\mathrm{N} 60^{\circ} \mathrm{W}$ orientation. They crop out over a large area $(150 \times 40 \mathrm{~km})$ spreading between the Androy massif and the lava flows on the southwestern side of the island. These dykes, which occur predominantly in clusters, are tens of meters to several $\mathrm{km}$ long with thicknesses varying between $1 \mathrm{~m}$ and a few tens of meters. Tholeiitic basalts occur as both lava flows and dykes while rocks of alkali composition are found only as dykes. Field observations suggest that the tholeiitic and alkali basalts are approximately contemporaneous.

The tholeiitic basalts show textures ranging from fine-grained sparsely porphyritic to aphyric. They have a common mineral assemblage composed of olivine, clinopyroxene, plagioclase and opaques, Clinopyroxene (augite) and plagioclase are the dominant phenocryst and groundmass phases. Some samples contain minor amounts of pigeonite in the groundmass. A significant amount of Fe-Tioxide is present in the differentiated basalts.

The alkali basalts are fine- to mediumgrained rocks with a doleritic texture. The main microphenocryst phase is clinopyroxene ( $\mathrm{ti}$ taniferous augite) with subordinate olivine and Fe-Ti-oxide and occasionally plagioclase. In the most silica-undersaturated rocks, nepheline and clinopyroxene are the predominant groundmass phases with minor quantities of Fe-Ti-oxide and intergranular biotite and amphibole and accessory apatite.

The rocks are usually fresh although some samples display signs of alteration. The more altered samples contain altered glass and olivine replaced by secondary iddingsite. However, the petrographic evidence of alteration does not appear to correlate with the chemical composition. In several samples, we suspect that the low $K$ and $R b$ values are the result of rainwater leaching as has been demonstrated for the Kohala basalts by Feigenson et al. (1983). The abundances of other elements do not appear to be affected by the secondary processes. However, it is still necessary to use care 


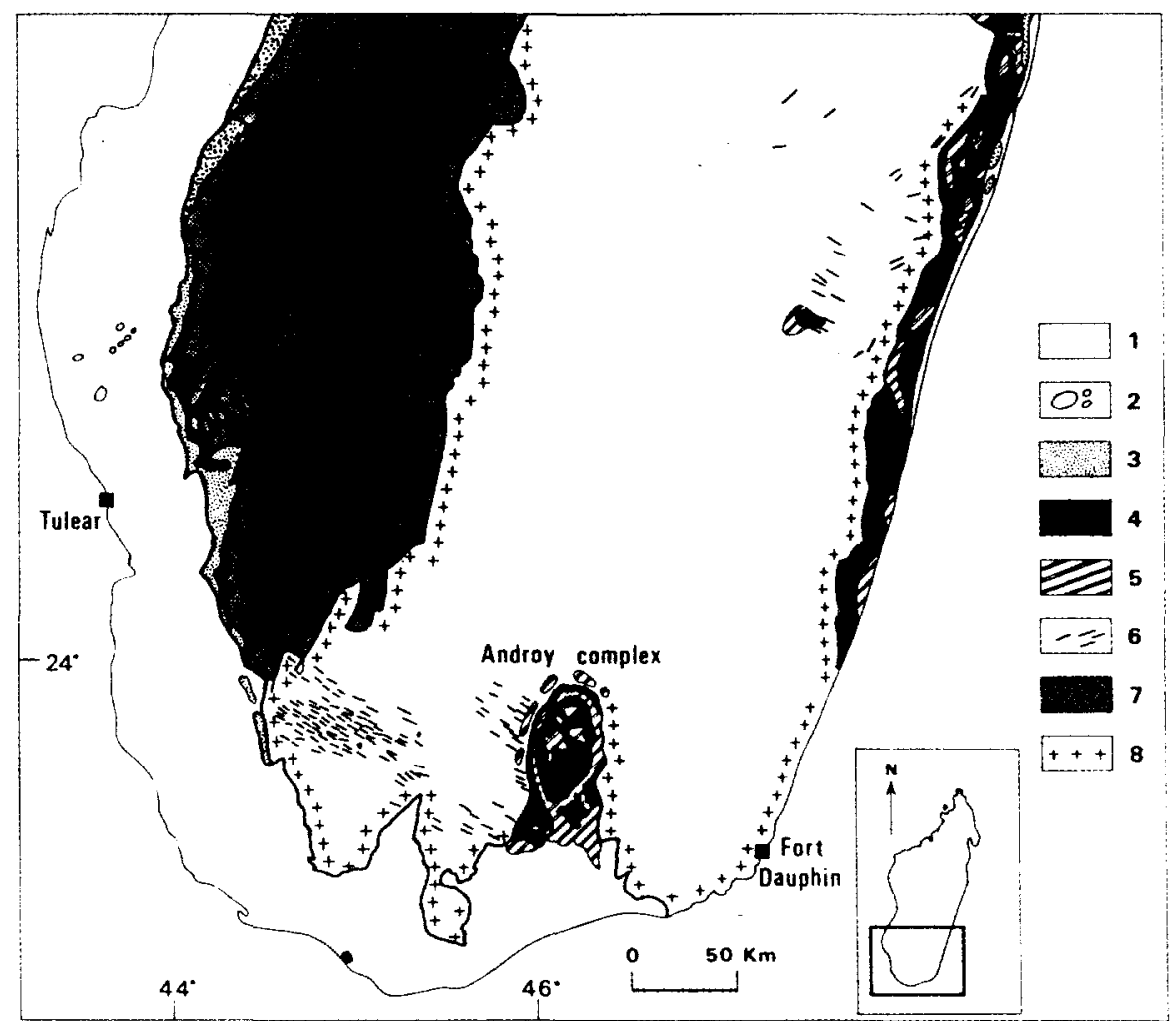

Fig. 1. Generalized geological map of southern Malagasy (modified after Nicollet, 1984). I=Eocene marine sediments; $2=$ Miocene basalts; $3=$ Maastrichtian sediments; 4, 5 and $6=$ Upper Cretaceous basalts, rhyolites and dykes, respectively; $7=$ Upper Carboniferous to Cretaceous sediments; $8=$ Precambrian basement.

in interpreting the distribution of some of the large-ion-lithophile elements (LILE).

\section{Sampling and analytical notes}

The samples of basaltic lavas and dykes were collected from accessible terrain throughout the southern one-third of the island. The major elements as well as trace elements $\mathrm{Ba}, \mathrm{Rb}, \mathrm{Sr}$, $\mathrm{Zr}, \mathrm{Nb}, \mathrm{Y}, \mathrm{Ni}, \mathrm{Cr}, \mathrm{V}, \mathrm{Cu}$ and $\mathrm{Zn}$ were determined by $\mathrm{X}$-ray fluorescence, whereas Li was analyzed by atomic absorption. From the set, thirty rocks were selected for instrumental neutron activation determinations of rare-earth elements (REE), Co, Th, Hf and Sc. The precision and accuracy of the data have been reported by Dostal et al. (1986) and are generally better than $\pm 10 \%$. The major- and traceelement analyses of representative basaltic la- vas and dykes are given in Table 1 . A complete set of the whole-rock analyses and locations of the samples can be obtained on request.

\section{Age determination}

Twenty-five samples were dated by the KAr method according to the analytical technique of Cantagrel and Baubron (1983) and the representative results are reported in Table 2 . The ages obtained for the tholeiites and alkali basalts overlap. Most of the values are between 65 and $79 \mathrm{Ma}$, while the rest of the data give mainly significantly younger ages, which are probably the result of Ar loss during alteration. This is particularly true for the samples of the western volcanic belt, where relatively young ages $(\sim 30 \mathrm{Ma})$ were obtained on tholeiitic flows intercalated with Maastrichtian and 
TABLE !

Chemical compositions of representative tholeiitic basalts from southern Malagasy

\begin{tabular}{|c|c|c|c|c|c|c|}
\hline \multirow{3}{*}{$\begin{array}{l}\text { Rock-type } \\
\text { Formation } \\
\text { Sample No. (wt.\%) }\end{array}$} & \multicolumn{6}{|c|}{ Evolved tholeiites } \\
\hline & \multicolumn{6}{|c|}{ Western belt } \\
\hline & 1 & 3 & 33 & 34 & 35 & 39 \\
\hline $\mathrm{SiO}_{2}$ & 52.06 & 50.06 & 49.70 & 48.54 & 49.66 & 51.45 \\
\hline $\mathrm{TiO}_{2}$ & 2.86 & 3.02 & 3.18 & 3.22 & 3.20 & 1.50 \\
\hline $\mathrm{Al}_{2} \mathrm{O}_{3}$ & 13.80 & 13.32 & 13.26 & 13.35 & 13.34 & 13.46 \\
\hline $\mathrm{Fe}_{2} \mathrm{O}_{3}$ & 13.22 & 14.68 & 14.50 & 15.11 & 15.32 & 13.89 \\
\hline $\mathrm{MnO}$ & 0.19 & 0.20 & 0.16 & 0.17 & 0.18 & 0.17 \\
\hline $\mathrm{MgO}$ & 4.36 & 4.00 & 4.19 & 4.80 & 4.92 & 4.73 \\
\hline $\mathrm{CaO}$ & 8.31 & 8.34 & 8.50 & 8.47 & 8.72 & 9.11 \\
\hline $\mathrm{Na}_{2} \mathrm{O}$ & 2.51 & 2.47 & 2.52 & 2.54 & 2.52 & 2.63 \\
\hline $\mathrm{K}_{2} \mathrm{O}$ & 1.33 & 1.50 & 0.88 & 0.72 & 0.90 & 0.86 \\
\hline $\mathrm{P}_{2} \mathrm{O}_{5}$ & 0.47 & 1.24 & 0.55 & 0.52 & 0.42 & 0.16 \\
\hline $\mathrm{H}_{2} \mathrm{O}^{+}$ & 0.98 & 0.92 & 1.49 & 0.97 & 0.21 & 1.21 \\
\hline $\mathrm{H}_{2} \mathrm{O}$ & 0.26 & 0.44 & 1.16 & 0.71 & 0.09 & 0.55 \\
\hline Total & $\overline{100.35}$ & $\overline{100.19}$ & $\overline{100.09}$ & 99.12 & 99.48 & 99.72 \\
\hline Mg-numbers & 0.43 & 0.38 & 0.39 & 0.41 & 0.42 & 0.43 \\
\hline $\mathrm{Li}(\mathrm{ppm})$ & 6 & 5 & 7 & 8 & 7 & 11 \\
\hline $\mathrm{Rb}$ & 46 & 48 & 32 & 26 & 30 & 31 \\
\hline $\mathrm{Sr}$ & 387 & 490 & 407 & 411 & 389 & 296 \\
\hline $\mathrm{Ba}$ & 389 & 552 & 378 & 420 & 306 & 363 \\
\hline $\mathrm{V}$ & 350 & 228 & 347 & 360 & 374 & 342 \\
\hline $\mathrm{Cr}$ & 32 & 35 & 28 & 40 & 43 & 6 \\
\hline$C_{0}$ & 42 & 37 & 46 & 48 & 45 & 47 \\
\hline $\mathrm{Ni}$ & 27 & 31 & 38 & 39 & 33 & 29 \\
\hline Sc & 26.2 & 24.8 & 24.6 & 23.9 & 27.6 & 28.9 \\
\hline $\mathrm{Cu}$ & 41 & 36 & 28 & 30 & 42 & 77 \\
\hline $\mathrm{Zn}$ & 134 & 144 & 136 & 138 & 140 & 114 \\
\hline $\mathrm{Y}$ & 36 & 38 & 35 & 33 & 32 & 29 \\
\hline $\mathrm{Zr}$ & 259 & 278 & 284 & 258 & 240 & 167 \\
\hline $\mathrm{Nb}$ & 19 & 19 & 19 & 21 & 17 & 9 \\
\hline $\mathrm{Hf}$ & 6.6 & 6.7 & 6.9 & 6.2 & 6.1 & 4.3 \\
\hline Th & 6.7 & 5.9 & 5.6 & 4.5 & 5.2 & 6.7 \\
\hline $\mathrm{La}$ & 31.5 & 39.9 & 31.1 & 27.3 & 27.1 & 23.6 \\
\hline $\mathrm{Ce}$ & 70.4 & 92 & 70.8 & 62.1 & 62.6 & 51.1 \\
\hline $\mathrm{Nd}$ & 43.3 & 51.2 & 42.1 & 36.7 & 37.8 & 28.6 \\
\hline $\mathrm{Sm}$ & 8.85 & 11.6 & 8.87 & 8.16 & 8.25 & 5.78 \\
\hline Eu & 2.45 & 3.81 & 2.73 & 2.56 & 2.48 & 1.51 \\
\hline $\mathrm{Tb}$ & 1.15 & 1.46 & 1.15 & 1.10 & 1.17 & 0.82 \\
\hline $\mathrm{Yb}$ & 3.00 & 3.13 & 2.95 & 2.80 & 2.86 & 2.90 \\
\hline $\mathrm{Lu}$ & 0.47 & 0.46 & 0.45 & 0.42 & 0.44 & 0.43 \\
\hline
\end{tabular}




\begin{tabular}{|c|c|c|c|c|c|c|c|c|}
\hline \multirow{2}{*}{\multicolumn{6}{|c|}{ Southwestern dyke swarm }} & \multicolumn{3}{|c|}{ Primitive tholeiites } \\
\hline & & & & & & \multicolumn{3}{|c|}{ Eastern belt } \\
\hline 46 & 47 & 49 & 50 & 54 & 55 & 58 & 59 & 60 \\
\hline 52.45 & 49.40 & 52.22 & 49.49 & 49.90 & 50.86 & 50.01 & 48.84 & 49.33 \\
\hline $2.4 !$ & 3.41 & 2.26 & 3.33 & 3.36 & 2.94 & 2.17 & 3.60 & 0.79 \\
\hline 12.88 & 13.50 & 13.00 & 13.47 & 13.53 & 12.94 & 13.73 & 12.75 & 20.40 \\
\hline 14.61 & 15.00 & 14.31 & 15.26 & 14.59 & 14.43 & 13.31 & 13.27 & 8.91 \\
\hline 0.21 & 0.20 & 0.22 & 0.19 & 0.20 & 0.20 & 0.18 & 0.15 & 0.12 \\
\hline 4.15 & 4.48 & 4.44 & 4.65 & 4.52 & 4.36 & 6.23 & 6.41 & 5.80 \\
\hline 7.94 & 8.17 & 7.86 & 8.22 & 8.14 & 8.35 & 10.45 & 10.00 & 11.18 \\
\hline 2.72 & 2.54 & 2.82 & 2.54 & 2.61 & 2.63 & 2.34 & 2.31 & 2.73 \\
\hline 1.07 & 1.36 & 1.40 & 1.20 & 1.54 & 1.10 & 0.28 & 0.49 & 0.20 \\
\hline 0.32 & 0.89 & 0.31 & 0.52 & 0.89 & 0.39 & 0.26 & 0.32 & 0.09 \\
\hline 0.46 & 0.16 & 0.82 & 0.32 & 0.31 & 0.51 & 0.41 & 0.87 & 0.40 \\
\hline 0.26 & 0.02 & 0.56 & 0.19 & 0.02 & 0.45 & 0.29 & 0.06 & 0.10 \\
\hline 99.48 & 99.13 & $\overline{100.22}$ & 99.38 & 99.61 & 99.16 & 99.66 & 99.07 & $\overline{100.05}$ \\
\hline 0.39 & 0.40 & 0.41 & 0.41 & 0.41 & 0.40 & 0.51 & 0.51 & 0.60 \\
\hline 5 & 6 & 12 & 10 & 9 & 9 & - & - & - \\
\hline 64 & 56 & 42 & 37 & 44 & 64 & 7 & 6 & 1 \\
\hline 276 & 458 & 255 & 402 & 455 & 286 & 252 & 546 & 376 \\
\hline 365 & 588 & 461 & 383 & 584 & 335 & 73 & 171 & 52 \\
\hline 390 & 300 & 361 & 355 & 300 & 358 & 329 & 452 & 131 \\
\hline 9 & 30 & 10 & 25 & 30 & 21 & 153 & 65 & 49 \\
\hline 45 & 43 & 45 & 46 & 44 & 46 & - & - & - \\
\hline 13 & 38 & 17 & 31 & 39 & 30 & 97 & 113 & 95 \\
\hline 31.6 & 23.3 & - & 24.9 & 23.1 & 28.8 & 35.8 & - & 19.1 \\
\hline 42 & 28 & 88 & 31 & 25 & 77 & 158 & 135 & 48 \\
\hline 131 & 143 & 124 & 152 & 151 & 147 & 100 & 101 & 63 \\
\hline 36 & 34 & 38 & 34 & 37 & 38 & 35 & 24 & 9 \\
\hline 244 & 272 & 232 & 276 & 267 & 260 & 145 & 207 & 51 \\
\hline 22 & 19 & 20 & 18 & 20 & 19 & 9 & 15 & 5 \\
\hline 6.2 & 6.4 & - & 6.7 & 6.4 & 6.5 & 3.6 & - & 1.1 \\
\hline 7.4 & 5.8 & - & 5.2 & 5.6 & 4.9 & 0.8 & - & 0.35 \\
\hline 29.9 & 51.5 & - & 29.1 & 34.1 & 26.9 & 9.70 & - & 3.80 \\
\hline 65.7 & 78.7 & - & 66.9 & 77.7 & 60.6 & 24.4 & -- & 9.10 \\
\hline 28.1 & 48.2 & - & 41.2 & 45.7 & 34.4 & 17.00 & - & 6.80 \\
\hline 7.75 & 9.72 & - & 8.75 & 9.62 & 8.47 & 5.48 & - & 1.74 \\
\hline 2.16 & 3.13 & - & 2.67 & 3.09 & 2.41 & 1.84 & - & 0.97 \\
\hline 1.08 & 1.15 & - & 1.21 & 1.18 & 1.17 & 1.25 & - & 0.39 \\
\hline 3.61 & 3.41 & - & 2.98 & 2.96 & 3.62 & 3.30 & - & 0.85 \\
\hline $0.5 ?$ & 0.49 & - & 0.45 & 0.47 & 0.53 & 0.52 & - & 0.13 \\
\hline
\end{tabular}


TABLE 1 (continued)

\begin{tabular}{|c|c|c|c|c|c|c|c|}
\hline \multirow{3}{*}{$\begin{array}{l}\text { Formation } \\
\text { Rock type } \\
\text { Sample No. }\end{array}$} & \multicolumn{7}{|c|}{ Southwestern dyke swarm } \\
\hline & \multicolumn{7}{|c|}{ Alkali basalts } \\
\hline & 2 & 8 & 10 & 11 & 12 & 16 & 18 \\
\hline $\mathrm{SiO}_{2}(\%)$ & 46.86 & 46.65 & 48.02 & 48.06 & 47.06 & 46.00 & 45.88 \\
\hline $\mathrm{TiO}_{2}$ & 1.48 & 1.81 & 1.86 & 1.98 & 1.96 & 1.01 & 1.62 \\
\hline $\mathrm{Al}_{2} \mathrm{O}_{3}$ & 15.27 & 15.31 & 16.72 & 17.19 & 17.00 & 13.52 & 16.93 \\
\hline $\mathrm{Fe}_{2} \mathrm{O}_{3}$ & 10.77 & 12.42 & 12.90 & 13.65 & 13.40 & 10.30 & 12.53 \\
\hline $\mathrm{MnO}$ & 0.16 & 0.18 & 0.18 & 0.18 & 0.18 & 0.17 & 0.19 \\
\hline $\mathrm{MgO}$ & 9.55 & 9.06 & 5.86 & 5.52 & 5.50 & 12.72 & 7.19 \\
\hline $\mathrm{CaO}$ & 11.73 & 9.72 & 8.10 & 7.88 & 7.67 & 12.03 & 9.60 \\
\hline $\mathrm{Na}_{2} \mathrm{O}$ & 2.57 & 2.98 & 3.77 & 4.09 & 3.88 & 2.02 & 3.00 \\
\hline $\mathrm{K}_{2} \mathrm{O}$ & 0.52 & 0.88 & 1.01 & 1.20 & 1.10 & 0.32 & 0.55 \\
\hline $\mathrm{P}_{2} \mathrm{O}_{5}$ & 0.23 & 0.44 & 0.47 & 0.47 & 0.47 & 0.21 & 0.31 \\
\hline $\mathrm{H}_{2} \mathrm{O}^{+}$ & 1.03 & 0.28 & 0.42 & 0.21 & 1.46 & 1.43 & 2.20 \\
\hline $\mathrm{H}_{2} \mathrm{O}^{-}$ & 0.18 & 0.04 & 0.25 & 0.14 & 0.40 & 0.06 & 0.32 \\
\hline Total & 100.35 & 99.77 & 100.08 & 100.57 & 100.08 & 99.79 & 100.32 \\
\hline Mg-numbers & 0.67 & 0.62 & 0.48 & 0.48 & 0.48 & 0.73 & 0.56 \\
\hline Li (ppm) & 5 & 9 & 9 & 11 & 9 & 7 & 8 \\
\hline $\mathrm{Rb}$ & 12 & 22 & 21 & 30 & 22 & 5 & 10 \\
\hline $\mathrm{Sr}$ & 335 & 316 & 624 & 657 & 631 & 268 & 604 \\
\hline $\mathrm{Ba}$ & 457 & 500 & 784 & 781 & 847 & 1,229 & 602 \\
\hline V & 300 & 218 & 190 & 173 & 177 & 252 & 210 \\
\hline $\mathrm{Cr}$ & 500 & 450 & 70 & 41 & 20 & 735 & 118 \\
\hline $\mathrm{Co}$ & 49 & 49 & 41 & 41 & 41 & 57 & 45 \\
\hline $\mathrm{Ni}$ & 184 & 122 & 54 & 36 & 20 & 294 & 73 \\
\hline $\mathrm{Sc}$ & 45.3 & 32.9 & 26.0 & - & 22.5 & 39.0 & 28.0 \\
\hline $\mathrm{Cu}$ & 113 & 56 & 33 & 36 & 35 & 90 & 15 \\
\hline $\mathrm{Zn}$ & 73 & 91 & 92 & 95 & 93 & 63 & 87 \\
\hline $\mathrm{Y}$ & 27 & 34 & 32 & 33 & 33 & 24 & 24 \\
\hline $\mathrm{Zr}$ & 123 & 194 & 161 & 178 & 176 & 74 & 139 \\
\hline $\mathrm{Nb}$ & 16 & 24 & 28 & 35 & 34 & 14 & 23 \\
\hline Hf & 2.9 & 4.4 & 3.8 & - & 3.9 & 1.6 & 3.1 \\
\hline Th & 1.3 & 2.1 & 3.4 & - & 3.8 & 1.0 & 2.1 \\
\hline $\mathrm{La}$ & 14.6 & 19.8 & 36.6 & - & 39.2 & 11.1 & 20.8 \\
\hline $\mathrm{Ce}$ & 31.8 & 44.1 & 74.1 & - & 80.1 & 23.8 & 44.3 \\
\hline $\mathrm{Nd}$ & 20.3 & 27.3 & 42.8 & - & 40.7 & 12.7 & 23.7 \\
\hline $\mathrm{Sm}$ & 4.63 & 6.26 & 7.21 & - & 7.48 & 3.20 & 4.84 \\
\hline $\mathrm{Eu}$ & 1.55 & 1.95 & 2.22 & - & 2.31 & 1.10 & 1.58 \\
\hline $\mathrm{Tb}$ & 0.99 & 1.22 & 1.18 & - & 1.22 & 0.67 & 0.84 \\
\hline $\mathrm{Yb}$ & 2.80 & 3.52 & 3.23 & - & 3.10 & 2.28 & 2.27 \\
\hline $\mathrm{Lu}$ & 0.46 & 0.58 & 0.52 & - & 0.51 & 0.37 & 0.37 \\
\hline
\end{tabular}

$\mathrm{Mg}$-number $=\mathrm{Mg} /\left(\mathrm{Mg}+\mathrm{Fe}^{2+}\right)$ with $\mathrm{Fe}^{3+} / \mathrm{Fe}^{2+}$ assumed to be 0.15. - = no data. 


\begin{tabular}{|c|c|c|c|c|c|c|c|c|}
\hline \multirow[b]{3}{*}{23} & \multirow[b]{3}{*}{31} & \multirow[b]{3}{*}{43} & \multirow[b]{3}{*}{44} & \multirow[b]{3}{*}{45} & \multicolumn{4}{|c|}{ Southwestern dyke swarm } \\
\hline & & & & & \multicolumn{4}{|l|}{ Basanites } \\
\hline & & & & & 7 & 20 & 24 & 52 \\
\hline 45.40 & 46.25 & 45.68 & 44.47 & 45.27 & 44.06 & 43.22 & 45.40 & 44.04 \\
\hline 1.91 & 1.52 & 1.43 & 1.39 & 2.26 & 1.77 & 1.64 & 1.58 & 1.04 \\
\hline 16.70 & 14.85 & 15.38 & 16.47 & 16.05 & 14.51 & 15.47 & 16.07 & 14.60 \\
\hline 12.94 & 11.61 & 11.89 & 11.14 & 13.75 & 11.38 & 10.64 & 11.69 & 10.43 \\
\hline 0.20 & 0.19 & 0.18 & 0.18 & 0.20 & 0.14 & 0.18 & 0.19 & 0.18 \\
\hline 6.55 & 10.57 & 10.32 & 8.88 & 7.67 & 10.13 & 9.00 & 9.35 & 11.13 \\
\hline 9.22 & 11.39 & 11.38 & 11.94 & 8.85 & 10.77 & 9.85 & 11.42 & 13.43 \\
\hline 3.57 & 2.69 & 2.22 & 2.40 & 3.68 & 4.11 & 3.08 & 2.90 & 2.50 \\
\hline 0.63 & 0.60 & 0.27 & 0.70 & 0.71 & 1.26 & 1.63 & 0.63 & 0.62 \\
\hline 0.41 & 0.38 & 0.17 & 0.21 & 0.38 & 0.88 & 0.46 & 0.42 & 0.40 \\
\hline 1.81 & 0.61 & 0.32 & 2.26 & 0.30 & 0.93 & 4.38 & 0.68 & 1.05 \\
\hline 0.48 & 0.09 & 0.12 & 0.27 & 0.09 & 0.18 & 0.47 & 0.10 & 0.18 \\
\hline 99.82 & $\overline{100.75}$ & 99.36 & $\overline{100.31}$ & 99.21 & 100.12 & 100.02 & $\overline{100.43}$ & 99.30 \\
\hline 0.53 & 0.67 & 0.66 & 0.64 & 0.56 & 0.67 & 0.65 & 0.64 & 0.70 \\
\hline 9 & 6 & 6 & 13 & 8 & 8 & 13 & 7 & 7 \\
\hline 16 & 16 & 5 & 13 & 17 & 30 & 40 & 15 & 17 \\
\hline 577 & 505 & 371 & 367 & 375 & 1,185 & 860 & 556 & 592 \\
\hline 537 & 448 & 146 & 511 & 372 & 2,230 & 1,105 & 460 & 573 \\
\hline 210 & 263 & 297 & 264 & 212 & 200 & 193 & 250 & 268 \\
\hline 39 & 408 & 368 & 130 & 160 & 390 & 320 & 214 & 400 \\
\hline 46 & 53 & 56 & 48 & 52 & 52 & 44 & 52 & 52 \\
\hline 54 & 194 & 146 & 109 & 113 & 204 & 168 & 168 & 225 \\
\hline 25.9 & 37.6 & 37.9 & 36.3 & 25.7 & 23.2 & 25.7 & - & 36.2 \\
\hline 40 & 82 & 69 & 71 & 56 & 71 & 64 & 90 & 114 \\
\hline 82 & 77 & 84 & 76 & 90 & 91 & 58 & 81 & 79 \\
\hline 30 & 24 & 22 & 26 & 30 & 26 & 27 & 28 & 24 \\
\hline 161 & 138 & 105 & 112 & 183 & 211 & 172 & 144 & 119 \\
\hline 37 & 32 & 11 & 23 & 30 & 62 & 68 & 32 & 30 \\
\hline 3.6 & 3.2 & 2.5 & 2.5 & 4.3 & 4.0 & 3.2 & - & 2.3 \\
\hline 3.5 & 3.6 & 0.90 & 1.3 & 1.8 & 10.5 & 4.1 & - & 4.8 \\
\hline 33.4 & 37.6 & 10.0 & 12.0 & 17.8 & 89.6 & 35.6 & - & 39.3 \\
\hline 68.5 & 75.9 & 23.1 & 27.0 & 40.1 & 170 & 68.3 & - & 77.8 \\
\hline 33.5 & 35.3 & 13.0 & 12.4 & 22.2 & 78.7 & 33.4 & - & 36.1 \\
\hline 6.36 & 6.26 & 3.83 & 4.06 & 6.24 & 11.5 & 5.83 & - & 6.32 \\
\hline 2.07 & 1.95 & 1.35 & 1.42 & 2.15 & 3.30 & 1.88 & - & 1.86 \\
\hline 1.25 & 0.90 & 0.77 & 0.95 & 1.39 & 0.95 & 0.98 & - & 0.69 \\
\hline 2.98 & 2.45 & 2.32 & 2.66 & 2.97 & 1.87 & 2.71 & - & 2.23 \\
\hline 0.49 & 0.40 & 0.35 & 0.39 & 0.43 & 0.30 & 0.43 & - & 0.37 \\
\hline
\end{tabular}


TABLE 2

$\mathrm{K}$-Ar results for representative samples

\begin{tabular}{|c|c|c|c|c|}
\hline Sample & $\begin{array}{l}K \\
(w t \%)\end{array}$ & $\begin{array}{l}{ }^{40} \mathrm{Ar} \\
\left(\mathrm{ng} \mathrm{g}^{-1}\right)\end{array}$ & $\begin{array}{l}\mathrm{Ar} \\
(\mathrm{at} \%)\end{array}$ & $\begin{array}{l}t \\
(\mathrm{Ma})\end{array}$ \\
\hline \multicolumn{5}{|l|}{ Western belt: } \\
\hline$I$ tholeiite & 1.12 & 3.61 & 39 & $46 \pm 0.9$ \\
\hline 3 tholeiite & 1.29 & 4.73 & 27 & $52 \pm 1$ \\
\hline 34 tholeiite & 0.649 & 2.45 & 36 & $54 \pm 1$ \\
\hline 39 tholeiite & 0.713 & 1.54 & 82 & $31 \pm 2$ \\
\hline 35 tholeiite & 0.763 & 1.96 & 82 & $37 \pm 2$ \\
\hline \multicolumn{5}{|c|}{ Southwestern dyke swarm: } \\
\hline 8 alkali basalt & 0.753 & 3.63 & 33 & $68 \pm 1$ \\
\hline 11 alkali basalt & 0.889 & 4.29 & 21 & $68 \pm 1$ \\
\hline 24 basanite & 0.579 & 2.68 & 35 & $66 \pm 1$ \\
\hline 10 alkali basalt & 0.839 & 4.10 & 27 & $69 \pm 1$ \\
\hline 45 alkali basalt & 0.625 & 3.32 & 28 & $75 \pm 2$ \\
\hline 52 basanite & 0.532 & 2.67 & 80 & $71 \pm 3$ \\
\hline 49 tholeiite & 1.10 & 5.01 & 18 & $65 \pm 1$ \\
\hline 54 tholeiite & 1.34 & 6.12 & 11 & $65 \pm 1$ \\
\hline \multicolumn{5}{|c|}{ Androy massif: } \\
\hline E 12 tholeiite & 1.26 & 6.02 & 23 & $68 \pm 1$ \\
\hline E 16 tholeiite & 1.52 & 7.86 & 24 & $72 \pm 1$ \\
\hline \multicolumn{5}{|l|}{ Eastern belt: } \\
\hline 58 tholeiite & 0.240 & 1.10 & 56 & $65 \pm 1$ \\
\hline 59 tholeiite & 0.419 & 2.34 & 36 & $79 \pm 2$ \\
\hline 60 tholeiite & 0.160 & 0.85 & 72 & $75 \pm 2$ \\
\hline
\end{tabular}

Ages were calculated using the 1977 constants.

Campanian (66-72 and 72-83 Ma ago, respectively; Haq and van Eysinga, 1987) sediments (Besairie and Collignon, 1972). Since these rocks do not appear to be more altered than similar lavas from the eastern belt, the young ages could also be related to recent faulting or fluid circulation and/or thermal partial resetting of the $\mathrm{K}$-Ar system associated with Upper Miocene to Quaternary alkali volcanism. The basaltic sequence in western Malagasy rests upon Turonian ( $>89 \mathrm{Ma}$ ago ) sediments, whereas along the eastern coast, marine Maastrichtian sediments are transgressive on top of the basaltic lava (Besairie and Collignon, 1972; Boast and Nairn, 1982). We believe that the true age of the Late Mesozoic volcanism in southern Malagasy is within the range of 65 to $83 \mathrm{Ma}$.
The Malagasy volcanism is not related to the older Karoo volcanism and also postdates the opening of the Mozambique channel which appeared during the separation of Malagasy from Africa (Norton and Sclater, 1979; Segoufin and Patriat, 1981). The timing of the emplacement of the basaltic rocks in southern Malagasy is close to but slightly older than the eruption of the Deccan Traps in India, where volcanic activity peaked around $66 \mathrm{Ma}$ ago (Courtillot et al., 1986, 1988; R.A. Duncan and Pyle, 1988), the peak of igneous activities at the Seychelles Islands dated at $63 \mathrm{Ma}$ (Dickin et al., 1986) and the initiation of the opening of the Arabian Sea (Courtillot et al., 1986). The volcanic activity appears to be closely related to the continental rifting and lithospheric thinning which must have been accompanied by mantle upwelling (White and McKenzie, 1989).

\section{Geochemistry}

\subsection{Major elements}

The basaltic rocks from southern Malagasy (Table 1 ) show a large range of chemical composition. On the basis of normative composition (assuming $\mathrm{Fe}^{3+} / \mathrm{Fe}^{2+}=0.15$ ), three types of basalts may be recognized:

(1) quartz-normative tholeiites (1-7\% norm. quartz) associated with a subordinate amount of olivine-normative tholeiites;

(2) alkali basalts ( $<5 \%$ norm. nepheline);

(3) basanites (5-15\% norm. nepheline).

The two latter types are limited to the southernmost part of the island where they appear as dykes, whereas the tholeiites are from the lava flows on both sides of the island and from the dyke swarm in southern Malagasy (Fig. 1).

The tholeiites can be further subdivided into two groups. The lavas from the western part of the island and the dykes are strongly fractionated with the $\mathrm{Mg}$-number $\left[\mathrm{Mg} /\left(\mathrm{Mg}+\mathrm{Fe}^{2+}\right)\right.$ assuming $\mathrm{Fe}^{3+} / \mathrm{Fe}^{2+}=0.15$ ] clustering around 0.40 whereas the tholeiitic basalts from the eastern side are more primitive with the $\mathrm{Mg}$ - 
number between 0.60 and 0.51 (Fig. 2). There is no obvious compositional difference between tholeiites from the lavas of the western belt and the dykes and thus all these evolved basalts are considered together. The evolved tholeiites have a composition similar to that of continental flood basalts from Karoo, South Africa (e.g., Erlank, 1984; Marsh, 1987; Cox, 1988a) and Paraná, Brazil, provinces (e.g., Mantovani et al., 1985; Piccirillo et al., 1989). They usually have low $\mathrm{MgO}(4-5 \%)$ but high $\mathrm{Fe}_{2} \mathrm{O}_{3}^{\mathrm{T}}(13-16.5 \%)$ and variable $\mathrm{TiO}_{2}$ and $\mathrm{P}_{2} \mathrm{O}_{5}$ contents. The latter two oxides separate the rocks into two relatively homogeneous groups. The first group, which encompasses a large majority of the tholeiite samples, has higher contents of $\mathrm{TiO}_{2}(>2 \%$; average $3.03 \%$ ) and $\mathrm{P}_{2} \mathrm{O}_{5}(>0.3 \%$; average $0.59 \%)$ than the second group which includes only two samples (average $1.5 \% \mathrm{TiO}_{2}$ and $0.17 \% \mathrm{P}_{2} \mathrm{O}_{5}$ ). Similar high- and low-Ti groups of tholeiitic basalts have been reported from the Karoo and Paraná flood basalt provinces (Bellieni et al., 1984; A.R. Duncan et al., 1984; Cox, 1988a ). Like in Karoo and Paraná (e.g., Erlank et al., 1988), the two groups of evolved tholeiites do not show any obvious differences in mineralogy, petrography or field occurrence. In the high- $\mathrm{Ti}$ tholeiites, $\mathrm{SiO}_{2}$ (on volatile-free basis) ranges from $49 \%$ to $52.5 \%$. The major-element variations which are relatively small include a rough positive correlation of $\mathrm{Al}_{2} \mathrm{O}_{3}$ and $\mathrm{CaO}$ with $\mathrm{Mg}$ number accompanied by a low and relatively constant $\mathrm{Al}_{2} \mathrm{O}_{3} / \mathrm{CaO}$ ratio (Fig. 2). The primitive tholeiites from eastern Malagasy are lower in $\mathrm{K}$ and some strongly incompatible trace ele-

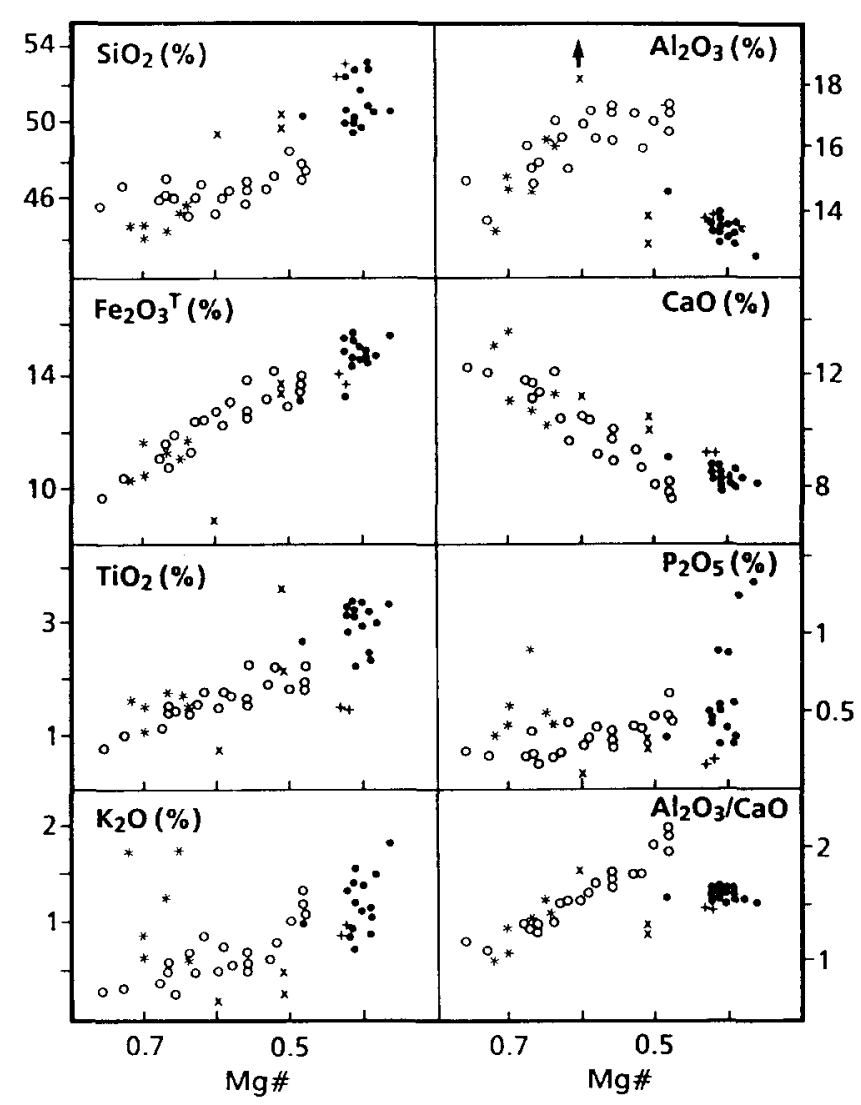

Fig. 2. Plots of $\mathrm{SiO}_{2}, \mathrm{Al}_{2} \mathrm{O}_{3}, \mathrm{Fe}_{2} \mathrm{O}_{3}^{\mathrm{T}}, \mathrm{CaO}, \mathrm{TiO}_{2}, \mathrm{P}_{2} \mathrm{O}_{5}$ and $\mathrm{K}_{2} \mathrm{O}$ contents and $\mathrm{Al}_{2} \mathrm{O}_{3} / \mathrm{CaO}$ ratio against $\mathrm{Mg}$-number [ $\mathrm{Mg} /$ $\left(\mathrm{Mg}+\mathrm{Fe}^{2+}\right)$ assuming $\left.\mathrm{Fe}^{3+} / \mathrm{Fe}^{2+}=0.15\right]$ for the basaltic rocks of Malagasy: evolved tholeiites - high-Ti rocks ( $)$, low-Ti rocks $(+)$; primitive tholeiites $(X)$; alkali basalts $(O)$; basanites $(*)$. 
ments such as Rb and light REE (LREE) than the evolved basalts (Fig. 3). Among the primitive tholeiites, sample 60 probably has accumulated plagioclase as indicated by its high $\mathrm{Al}_{2} \mathrm{O}_{3}$ content and a higher quantity of plagioclase phenocrysts $(\sim 20 \%)$.

The silica-undersaturated dyke rocks display a range of $\mathrm{Mg}$-number decreasing from 0.76 to 0.48 accompanied by a distinct increase of $\mathrm{Fe}$ and $\mathrm{Ti}$ with differentiation (Fig. 2 ). They are poorer in $\mathrm{SiO}_{2}$ than the tholeiites and have higher $\mathrm{Al}_{2} \mathrm{O}_{3} / \mathrm{CaO}$ ratios for a given $\mathrm{Mg}$-number than those of the high-Ti tholeiites (Fig. 2). Most major elements in the silicaundersaturated rocks inversely correlate with the $\mathrm{Mg}$-number, whereas $\mathrm{CaO}$ shows a positive correlation (Fig. 2). The $\mathrm{Al}_{2} \mathrm{O}_{3} / \mathrm{CaO}$ ratio increases with increasing differentiation (Fig. 2), giving values close to that of chondrites $\left(\mathrm{Al}_{2} \mathrm{O}_{3} / \mathrm{CaO}=1.1\right)$ in the most primitive undersaturated rocks. The increase of this ratio is the result of pyroxene fractionation. The basanites are higher in $\mathrm{K}$ and $\mathrm{P}$ and lower in $\mathrm{Si}$ than the alkali basalts (Fig. 2; Table 1).

\subsection{Trace elements}

\subsubsection{Transition elements. The low abun-} dances of the compatible transition elements, $\mathrm{Cr}$ and $\mathrm{Ni}$, in the evolved tholeiites (Fig. 3; Table 1 ) confirm that the rocks underwent extensive fractional crystallization involving ferromagnesian minerals. The primitive tholeiites have higher abundances of these elements but they are still significantly lower than those expected for primary mantle melts. The concentrations of $\mathrm{Cr}, \mathrm{Ni}, \mathrm{Sc}$ and $\mathrm{Co}$ in the silicaundersaturated dyke rocks decrease with differentiation, reflecting the crystallization of olivine and pyroxenes. In agreement with partition coefficients for clinopyroxene and olivine (Wedepohl, 1985), the decrease of Co accompanying the steeper decrease of $\mathrm{Ni}$ relative to the other transition elements down to $\mathrm{Mg}$ number $\approx 0.60$ (Fig. 3 ) in the silica-undersaturated dyke samples attests to the influence of olivine, in addition to clinopyroxene, in the first stage of differentiation.

The concentrations of $\mathrm{V}$ are higher in the tholeiites than in the undersaturated dyke rocks (Fig. 3; Table 1). In the latter rocks, V slightly increases with differentiation up to Mg-number $\approx 0.65$ and then starts to decrease, indicating the crystallization of Fe-Ti-oxides during more advanced stages of the differentiation. $\mathrm{Ti} / \mathrm{V}$ ratios in the tholeiites and silica-undersaturated dyke rocks are high (Table 3 ), usually $>40$; similar values are found in intraplate basalts (Shervais, 1982). The exceptions are the low-Ti basalts with a $\mathrm{Ti} / \mathrm{V}$ ratio $\sim 25$, which is still within the range typical of midocean ridge basalts (MORB) and continental tholeiites.

\subsubsection{Rare-earth elements. The chondrite-} normalized REE distribution of several representative basalts is shown in Fig. 4. The evolved high-Ti tholeiites have patterns enriched in LREE with $(\mathrm{La} / \mathrm{Yb})_{\mathrm{n}}$ ratios $(\mathrm{n}$ : chondritenormalized) between 5 and 10 and $\mathrm{La}_{\mathrm{n}}$ abundances ranging from 80 to 160 . The evolved low-Ti tholeiite has a similar REE pattern with $(\mathrm{La} / \mathrm{Yb})_{\mathrm{n}} \approx 5.4$ but slightly lower LREE abundances $\left(\mathrm{La}_{\mathrm{n}} \sim 70\right)$. The REE patterns and abundances of the evolved high- and low-Ti tholeiites (Fig. 4a) are comparable to those of equivalent rock-types from Paraná (Mantovani et al., 1985; Marques et al., 1988) and Karoo (Erlank et al., 1988). The tholeiitic basalts of the Deccan Traps have typically lower REE abundances and less fractionated patterns (Fig. 4b and Mahoney et al., 1982; Dupuy and Dostal, 1984; Lightfoot and Hawkesworth, 1988), although some basalts from the Bombay area (Dupuy and Dostal, 1984) have similar REE distributions. In fact, compared to the main basaltic types of the Deccan Traps (Cox and Hawkesworth, 1984, 1985; Mahoney et al., 1985; Lightfoot and Hawkesworth, 1988 ), the evolved tholeiites, particularly high$\mathrm{Ti}$ ones, have higher abundances not only of REE but also of many other incompatible ele- 

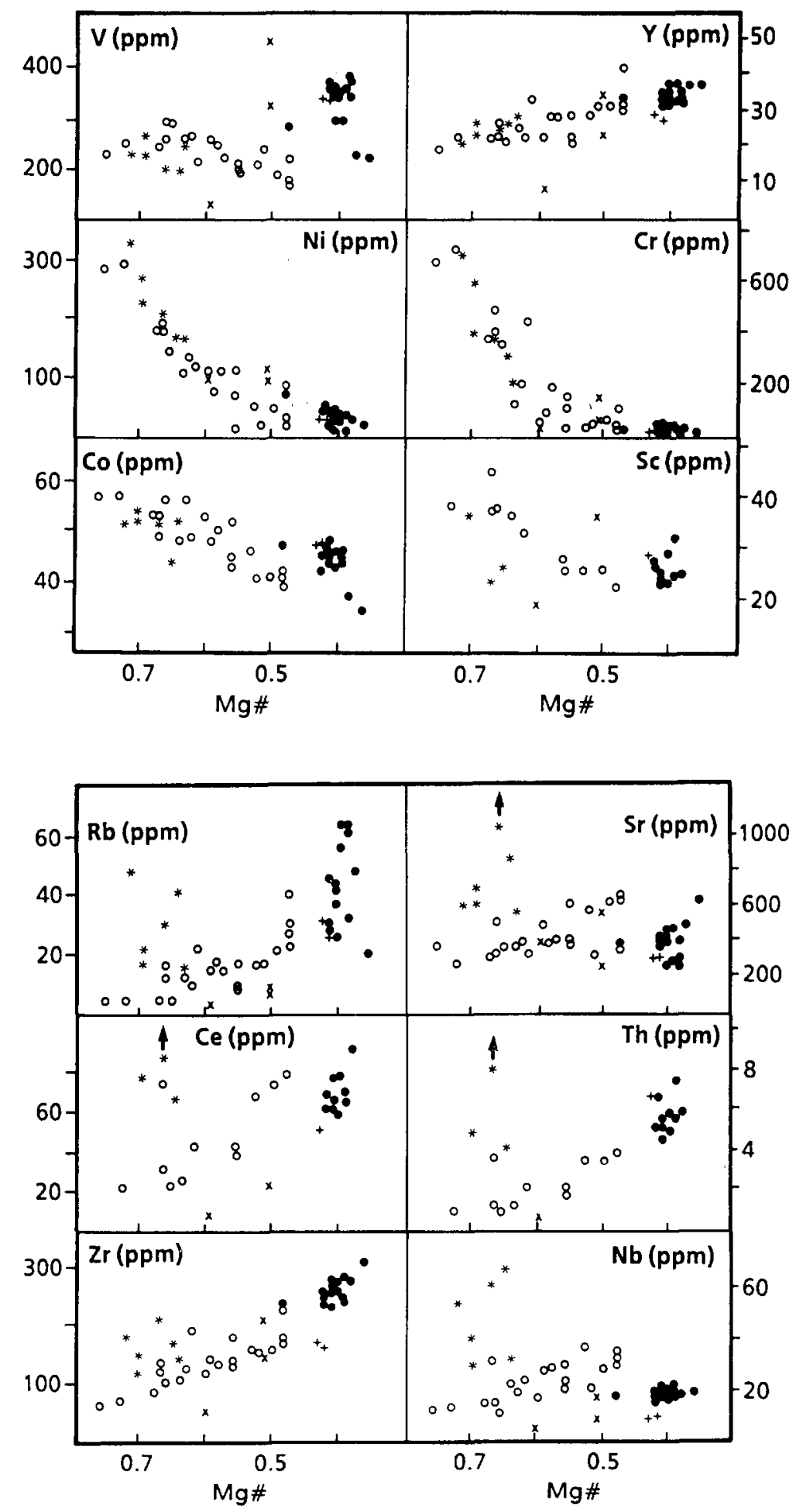

Fig. 3. Plots of selected trace elements against $\mathrm{Mg}$-number $\left[\mathrm{Mg} /\left(\mathrm{Mg}+\mathrm{Fe}^{2+}\right)\right.$ assuming $\left.\left.\mathrm{Fe}^{3+} / \mathrm{Fe}^{2+}=0.15\right)\right]$ for the basaltic rocks of Malagasy: evolved tholeiites - high-Ti types $(-)$, low-Ti rocks $(+)$; primitive tholeiites $(\times)$; alkali basalts $(O)$; basanites $(*)$. 


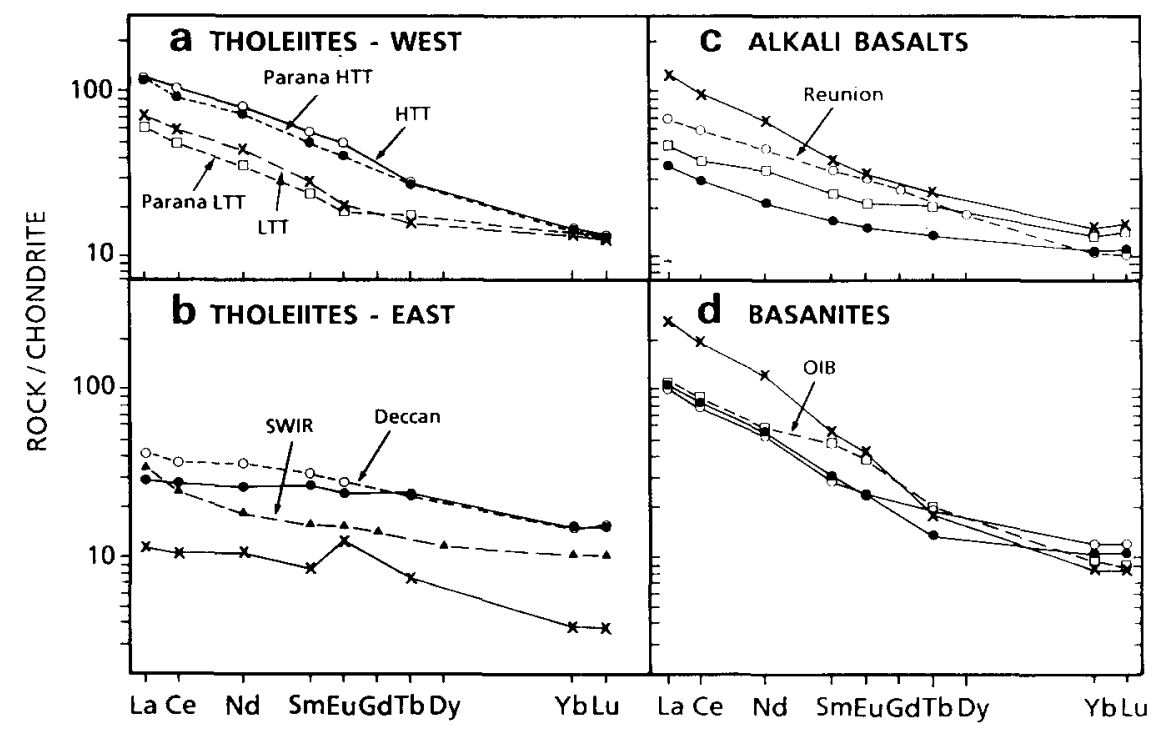

Fig. 4. Chondrite-normalized REE patterns for Malagasy tholeiites ( $a$ and b), alkali basalts (c) and basanites (d). Normalizing values after Masuda et al. (1973).

a. High-Ti $(H T T)(O=$ sample 3$)$ and low-Ti $(L T T)(\times=$ sample 39$)$ evolved tholeiites. The averages of HTT and LTT $(\square)$ from the Paraná Basin (Mantovani et al., 1985) are plotted for comparison.

b. Primitive tholeiites from eastern Malagasy $(O=$ sample $58 ; \times=$ sample 60 ) together with the average of the Deccan Trap basalts of the Ambenali Formation (Lightfoot and Hawkesworth, 1988) (O) and the average of E-type MORB from the Southwest Indian Ridge (SWIR) (Le Roex et al., 1989) ( $\mathbf{A}$ ).

c. Alkali basalts $(\square=$ sample $2 ; X=$ sample $12 ; O=$ sample 16 ) together with oceanic island basalts $(O)$ from Réunion Island (Newsom et al., 1986).

d. Basanites $(X=$ sample $7 ; O=$ sample $20 ; 0=$ sample 52) and average of oceanic island basalts ( $\square)$ of Sun and McDonough (1989).

ments and have higher $\mathrm{Zr} / \mathrm{Ti}, \mathrm{Ba} / \mathrm{Nb}$ and $\mathrm{Nb} /$ $Y$ ratios (Fig. 5).

Among the primitive tholeiites, sample 60 has the lowest REE abundances and its pattern is characterized by a positive Eu anomaly (Fig. 4b) which, along with its high $\mathrm{Al}_{2} \mathrm{O}_{3}$ content, confirms that the rock is plagioclase cumulate. On the other hand, sample 58 (Fig. $4 \mathrm{~b}$ ) has a relatively flat REE pattern with $(\mathrm{La} / \mathrm{Yb})_{\mathrm{n}} \approx 2$. The pattern somewhat resembles those of the Deccan Trap basalts (Mahoney et al., 1982; Dupuy and Dostal, 1984; Lightfoot and Hawkesworth, 1988) and enriched MORB including basalts from the Southwest Indian Ridge (Le Roex et al., 1983, 1985, 1989).

The REE patterns of the silica-undersaturated rocks are like those of oceanic island basalts (OIB) (Fig. 4c and d). The ( $\mathrm{La} / \mathrm{Yb})_{\mathrm{n}}$ ratio usually ranges between 2.9 and 10.3 in the alkali basalts and between 9 and 32 in the bas- anites. The La abundances are increasing from the alkali basalts with values of 30$120 \times$ chondrites to the basanites with $100-$ $280 \times$ chondritic concentrations. The highest LREE concentrations are encountered in basanite 7 (Table 1) which has 15\% normative nepheline. The most silica-undersaturated dyke rocks display a crossing of their REE patterns (Fig. 4d), which may be interpreted to be the result of a variable degree of partial melting from a common source leaving a residue with a variable garnet/clinopyroxene ratio (Kay and Gast, 1973).

\subsubsection{Incompatible elements ( $\mathrm{Ba}, \mathrm{Sr}, \mathrm{Rb}, \mathrm{Nb}$,} $\mathrm{Th}, \mathrm{Zr}, \mathrm{Hf}$ and $\mathrm{Y}$ ). The abundances of $\mathrm{Nb}, \mathrm{Ba}$ and $\mathrm{Sr}$ increase with the degree of undersaturation from tholeiites through alkali basalts to basanites (Fig. 3; Table 1). The trend is accompanied by a decrease of the $\mathrm{Zr} / \mathrm{Nb}$ and $\mathrm{Y} /$ 


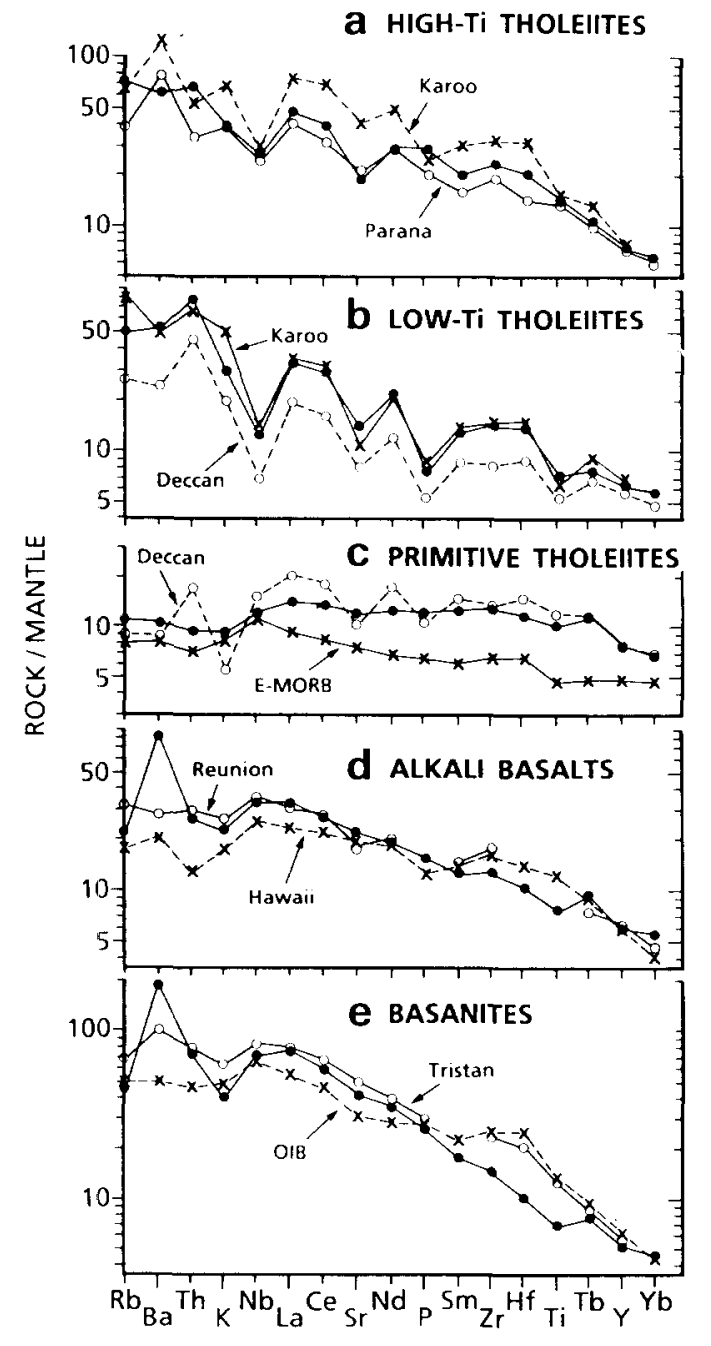

Fig. 5. Plots of incompatible-element abundances normalized to primitive mantle (Sun and McDonough, 1989) for selected basalts from southern Malagasy. Also plotted for comparison are the data for similar rocks. Normalizing values (in ppm): $\mathrm{Rb} 0.635, \mathrm{Ba} 6.989$, Th $0.085, \mathrm{~K}$ 250, Nb 0.713, La 0.687, Ce 1.775, Sr 21.1, Nd 1.354, P 95, Sm 0.444, Zr 11.2, Hf 0.309, Ti 1300, Tb 0.108, Y $4.55, \mathrm{Yb} 0.493$.

a. High-Ti tholeiites: =average of high- $\mathrm{Ti}$ tholeiites $\left(>2 \% \mathrm{TiO}_{2}\right)$ from southern Malagasy; $x=$ average of Karoo basalts from N. Lebombo (Sabie River basalts; A.R. Duncan et al., 1984; Marsh, 1987); $O=$ average of highTi tholeiites from northern Paraná (Marques et al., 1988). b. Low-Ti basalts: $=$ low-Ti tholeiite sample 39 from southwestern Malagasy; $X=$ average of Karoo basalts from Etendeka (Tafelberg basalts; A.R. Duncan et al., 1984; Marsh, 1987); $O=$ average of the Deccan Traps basalts from the Bushe Formation (Lightfoot and Hawkesworth, 1988).
$\mathrm{Nb}$ ratios (Table 3 ). On the other hand, Th and $\mathrm{Rb}$, like $\mathrm{K}$ are enriched in the evolved tholeiites which have contents of these elements close to those of the basanites (Figs. 2 and 3 ). When compared with the other analyzed basalts, the evolved tholeiites have a distinctly higher $\mathrm{Th} /$ $\mathrm{La}$ ratio and lower $\mathrm{Nb} / \mathrm{La}, \mathrm{Nb} / \mathrm{Th}$ and $\mathrm{K} / \mathrm{Rb}$ ratios (Table 3 ).

The variations of $\mathrm{Zr}$, Hf and $\mathrm{Y}$ in the alkali basalts and evolved tholeiites are mainly controlled by differentiation as these elements increase within each suite with the decrease of the Mg-number (Fig. 3; Table 1). The evolved high-Ti tholeiites have the highest contents of $\mathrm{Zr}$ and $\mathrm{Hf}$ (Fig. 3; Table 1). Like in Paraná and Karoo, they also have higher $\mathrm{Zr} / \mathrm{Y}$ (average 7.3) and $\mathrm{Ti} / \mathrm{Y}$ (average 508) ratios than the low-Ti basalts ( 5.8 and 320 , respectively). The basanites have generally higher $\mathrm{Zr}$ (Fig. 3 ) and lower Hf than alkali basalts with equivalent $\mathrm{Mg}$-number and thus possess a higher $\mathrm{Zr}$ / Hf ratio $(\sim 53)$ than the alkali basalts and tholeiites (Table 3). Such an increase of $\mathrm{Zr} / \mathrm{Hf}$ with the degree of silica-undersaturation has been observed in Hawaiian basalts in the Pacific (Clague and Frey, 1982) and seems to be a common feature among intraplate basalts (Weaver et al., 1987; Dautria et al., 1988; Dostal et al., 1988). It appears that $\mathrm{Zr}$ is more incompatible than $\mathrm{Hf}$ during the genesis of the strongly undersaturated basalts in the upper mantle. The $\mathrm{Hf} / \mathrm{Sm}$ and $\mathrm{Zr} / \mathrm{Sm}$ ratios have

c. Primitive tholeiites: $=$ primitive tholeiite sample 58 from eastern Malagasy; $x=$ average of E-type MORB of Sun and McDonough (1989); $O=$ average of the Deccan Traps basalts from the Ambenali Formation (Lightfoot and Hawkesworth, 1988 ).

d. Alkali basalts: =average of alkali basalts from southern Malagasy; also plotted for comparison are data on oceanic island basalts from Réunion ( $O$ ) (Newsom et al., 1986 ) and Hawaii $(x)$ (USGS standard rock BHVO-1; Gladney and Roelandts, 1988).

e. Basanites: = average of basanites from southern Malagasy; $\bigcirc=$ average of oceanic island basalts (moderately to mildy nepheline normative) from Tristan da Cunha (Weaver et al., 1987); $X=$ average of oceanic island basalts of Sun and McDonough (1989). 
near mantle values in the primitive tholeiitic basalts (Table 3 ) and decrease with the degree of silica-undersaturation towards the basanites. This suggests either an enrichment of LREE relative to high-field strength elements (HFSE) in the respective upper-mantle sources or element fractionation related to small but different degrees of melting.

\section{Discussion}

\subsection{Evolved tholeiites}

The differences between the high- and low$\mathrm{Ti}$ tholeiites are also reflected in several incompatible elements. The high-Ti tholeiites have higher contents of $\mathrm{P}, \mathrm{Zr}, \mathrm{Hf}, \mathrm{Nb}$ and LREE than the low-Ti rocks of similar Mgnumber (Fig. 3; Table 1). The same two groups (high-Ti or enriched and low-Ti or normal groups) have been documented in the Paraná and Karoo provinces. In the three provinces, equivalent rock-groups display close compositional similarities including mantle-normalized distribution patterns of incompatible trace elements (Fig. 5a and b). These patterns are hump-backed, marked by negative anomalies of $\mathrm{Nb}$ and $\mathrm{Sr}$ characteristic of continental tholeiites (Thompson et al., 1982). In addition, the profile of the low-Ti tholeiite displays a relative depletion in $\mathrm{P}$ and $\mathrm{Ti}$. The pattern mimics those of basalts from the Bushe Formation of the Deccan Traps and low-Ti Karoo basalts of Tafelberg, Etendeka (Fig. 5b) which have rather high initial $\mathrm{Sr}$-isotope ratios $(>0.715$, Cox and Hawkesworth, 1985; Beane et al., 1988 and $\sim 0.708-0.713$, Erlank et al., 1984, respectively).

Several detailed studies on Paraná and Karoo (e.g., Bellieni et al., 1984; Erlank et al., 1984) demonstrated that the compositional trends within each tholeiitic group can be modelled by low-pressure fractional crystallization of pyroxenes, plagioclase, olivine and $\mathrm{Fe}-$ Ti-oxides, which in the case of some low-Ti basalts was probably accompanied by crustal contamination. The observed variations of the evolved tholeiites from Malagasy are consistent with such a mechanism. However, fractional crystallization, even accompanied by crustal contamination or periodically replenished, tapped and fractionated magma chambers (O'Hara, 1977; Cox, 1988b), cannot explain the differences between the high- and lowTi tholeiites. In Paraná and Karoo, the two groups have been related to distinct parental magmas which have been either generated by varying degrees of partial melting of a homogeneous mantle source (Piccirillo et al., 1989: garnet peridotite $-5 \%$ melting for high-Ti and $20 \%$ for low-Ti basalts ) or derived from a heterogeneous mantle source. The recent isotope and trace-element data favor the heterogeneous source for the two groups (A.R. Duncan et al., 1988; Erlank et al., 1988; Peate et al., 1988; Piccirillo et al., 1989). The same origin can be invoked for the two groups of evolved tholeiites from Malagasy; the melts with their contrasting incompatible-element distribution patterns (Fig. 5) and element ratios (Table 3 ) cannot be readily derived from the same source by variable degrees of melting. The relative depletion of $\mathrm{Nb}, \mathrm{Sr}$ and, in low-Ti tholeiite, even of $\mathrm{P}$ and $\mathrm{Ti}$ (Fig. 5b) while alkali metals, Ba and $\mathrm{Th}$ are enriched, suggests the role of a crustal component in the genesis of these rocks. However, available data cannot determine whether the crustal signature is due to crustal contamination of magma or due to the presence of some crustal components in the source.

\subsection{Primitive tholeiites and silica- undersaturated dyke rocks}

The primitive tholeiites from the eastern side of southern Malagasy seem to be devoid of any crustal component. The ratio of Th/La which is frequently considered to be a sensitive indicator of crustal contamination is low in these rocks, close to the mantle value (Table 3 ). The mantle-normalized incompatible-element pattern of the primitive tholeiite 58 (Fig. $5 \mathrm{c}$ ) is 


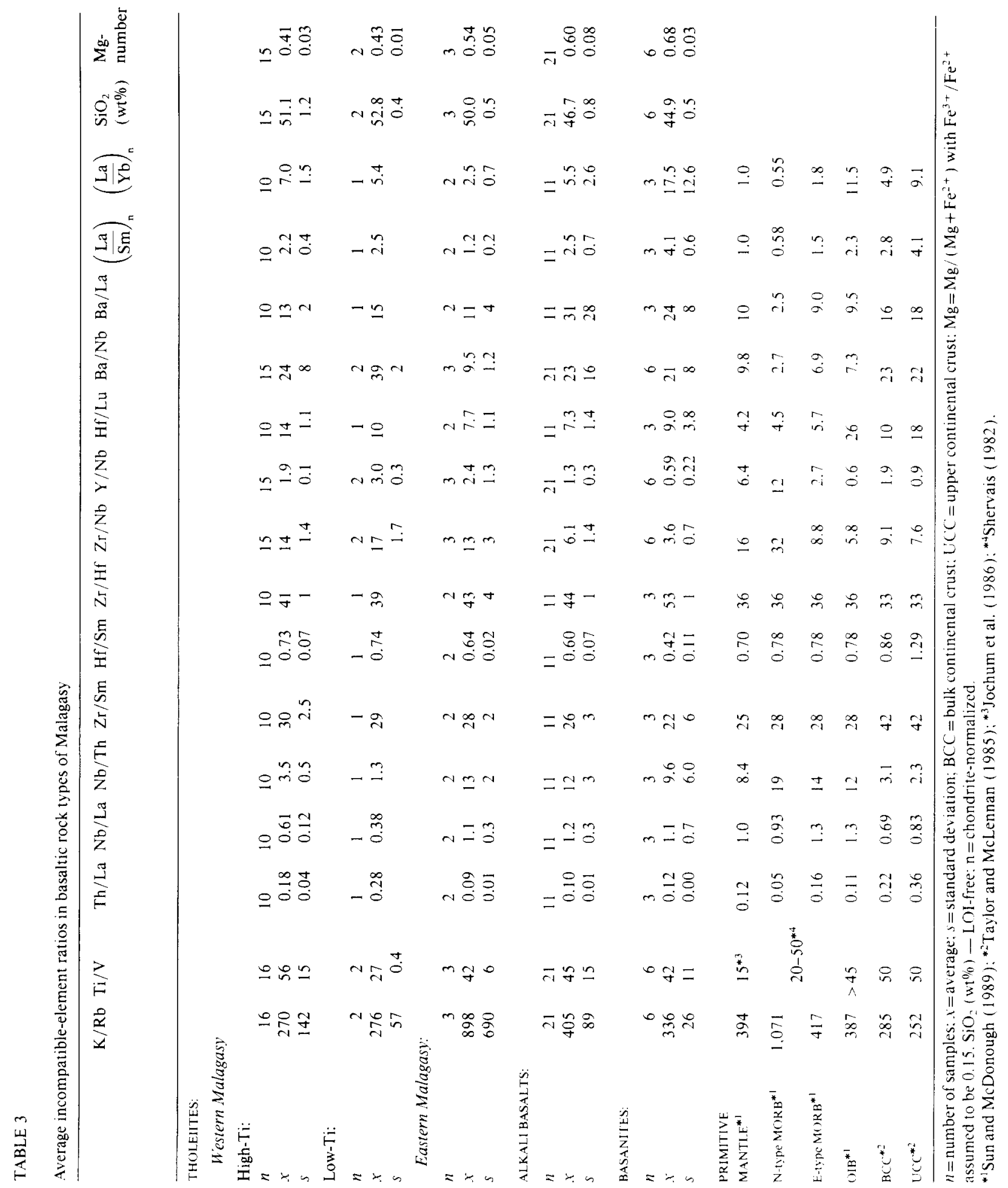


relatively flat and smooth and resembles those of E-type MORB including basalts from the southern and Indian Oceans (Le Roex et al., 1983, 1985, 1989). The tholeiite also shows some similarities to the basalts of the Ambenali Formation from the Deccan Traps (Fig. 5c) although there are some important compositional differences which are also depicted by the incompatible-element patterns. The primitive tholeiites are not directly related to the evolved basaltic types. Simple models of partial melting or fractional crystallization of a common parent cannot explain the differences in the trace-element characteristics including the shape of the mantle-normalized patterns and the incompatible-element ratios between these two basaltic types (Table 3 ). The primitive and evolved tholeiites were derived from different sources. However, the primitive tholeiites have ratios of several incompatible elements similar to those of the undersaturated dyke rocks (Table 3 ), suggesting that they were both derived from sources which share many geochemical features.

The mantle-normalized incompatible-element patterns of the silica-undersaturated dyke rocks resemble those of OIB (Fig. 5d and e). Compared to typical OIB, they are slightly enriched in $\mathrm{Ba}$ and depleted in $\mathrm{Zr}$, Hf and $\mathrm{Ti}$. The absolute abundances of incompatible elements in the alkali basalts are more similar to enriched oceanic island tholeiites than to typical alkali basalts. The alkali basalts and basanites were probably generated from a single source by variable degrees of melting. However, compared to the alkali basalts, the basanites have generally higher contents of strongly incompatible elements and higher La/Yb, but lower $\mathrm{Zr} / \mathrm{Nb}$ ratios (Table 3 ), suggesting a decrease of the degree of partial melting towards the most undersaturated rocks. In addition, the crossing of REE patterns in the basanites suggests that the decrease of the degree of partial melting was accompanied by an increase of garnet in the upper-mantle residue. This source had to be enriched in LILE relative to primor- dial mantle unless the degree of partial melting was $<1 \%$ for the basanites.

Close similarities of the primitive tholeiites to enriched MORB and of the undersaturated dyke rocks to the OIB suggest that the basaltic rocks from Malagasy were derived from an upwelling plume of hot mantle material. However, the abundances of Ba relative to the other strongly incompatible elements in the silicaundersaturated dyke rocks are elevated (Fig. $5 \mathrm{~d}$ and $\mathrm{e}$ ). The ratios such as $\mathrm{Ba} / \mathrm{Nb}$ and $\mathrm{Ba} /$ La which are usually not significantly affected by partial melting are also high in the undersaturated rocks (Table 3 ). Similar Ba enrichment encountered in OIB from Gough Island, South Atlantic Ocean (Weaver et al. 1987) has been interpreted as evidence for the presence of ancient subducted oceanic crust containing a small amount of Ba-rich pelagic sediments in the mantle source region.

\subsection{Geodynamic implications}

Cox (1988a) and Erlank et al. (1988) have delineated two major geochemical subprovinces in Karoo which can be extended into the Paraná basin in Brazil. The northern subprovince is composed of high-Ti basalts with subordinate amounts of low-Ti tholeiites while the southern subprovince contains only low- $\mathrm{Ti}$ tholeiites. The contact zone between two subprovinces in a reconstruction of southwestern Gondwanaland during the Mesozoic has been inferred to run $\mathrm{E}-\mathrm{W}$ across southern Africa and South America for almost $3000 \mathrm{~km}$. The magmatic activity in the two subprovinces lasted for at least $60 \mathrm{Ma}$ as most Karoo basalts in the Lebombo and Lesotho areas are $\sim 190 \mathrm{Ma}$ old whereas the age of the Etendeka and Paraná tholeiites is $\sim 130 \mathrm{Ma}$ (Erlank, 1984). The lateral extent and longevities of the boundary points to a large-scale heterogeneity of the mantle. Before the break-up and dispersion of Gondwanaland, Malagasy was located along the present southeastern edge of southern Africa. Since the evolved tholeiites closely resem- 
ble tholeiitic sequences from the high-Ti subprovinces of Karoo and Paraná, it may be speculated that the large-scale mantle heterogeneity within the Gondwanaland lithospheric mantle extended up to Malagasy. Sweeney and Watkeys (in Erlank et al., 1988) argued that the subprovinces are related to the different lithospheric domains. The high-Ti basalts usually lie on top of the Archean basement which has been stable since $\sim 2.5 \mathrm{Ga}$ whereas the low$\mathrm{Ti}$ basalts overlie post-Archean crust. However, the southwestern part of Malagasy is underlain by the Proterozoic crust (Besairie and Collignon, 1972; Boast and Nairn, 1982), suggesting that the enriched subcontinental lithospheric mantle may also be present under a younger post-Archean crust. The rising mantle plume, from which the primitive tholeiites and the undersaturated rocks were probably derived, could have induced lithospheric melting (White and McKenzie, 1989) which produced the parent magmas of the evolved tholeiites.

\section{Conclusions}

The Upper Cretaceous basaltic rocks of southern Malagasy include evolved tholeiites with $\mathrm{Mg}$-number $\approx 0.4$, relatively primitive tholeiites with $\mathrm{Mg}$-number ranging from 0.6 to 0.5 and silica-undersaturated basaltic dyke rocks. The evolved tholeiites have a composition typical of high-Ti basalts from the Karoo and Paraná flood basalt provinces. They were derived from subcontinental lithosphere which could have been an extension of an enriched domain within the Gondwanaland lithospheric mantle that stretched from South America to southern Africa. The occurrence of rare low-Ti tholeiites in the high-Ti basalt sequence points to smaller-scale heterogeneities within the enriched lithosphere domain.

The primitive tholeiitic basalts are compositionally similar to E-type MORB and are not directly related to the evolved tholeiites. Alkali basalts and basanites resemble OIB. Their distribution of heavy REE is consistent with gar- net as a residual phase. The primitive tholeiites share some geochemical features, particularly several element ratios (Table 3 ), with the silica-undersaturated dyke rocks. Such a relationship may be the result of derivation from a similar source by varying degrees of melting. In the absence of isotope data it is difficult to constrain the composition of such a source. However, it may be speculated that the mantle source contained a recycled oceanic crust component to account for the enrichment of $\mathrm{Ba}$ in the silica-undersaturated dyke rocks.

The volcanism is probably related to an upwelling plume of hot mantle material. McDonough et al. (1985) have postulated that for OIB and continental intraplate basalts, the composition of the tholeiites more directly reflects the nature of the plume component than that of alkali basalts. Thus, the primitive tholeiites such as sample 58 may provide evidence of a hot spot trace in southern Malagasy. The rising of the plume triggered extensive melting within the subcontinental lithosphere (White and McKenzie, 1989) under Malagasy which generated the voluminous evolved tholeiites.

The Mesozoic basaltic volcanism of Malagasy displays many similarities to other flood basalt provinces, including large volumes, rock compositions and emplacement near plate margins. The timing of the Malagasy magmatic activities is close to but probably slightly before the emplacement of the Deccan continental flood basalts in western India, where volcanic eruptions probably coincided with the Cretaceous-Tertiary boundary (Courtillot et al., 1986, 1988; R.A. Duncan and Pyle, 1988 ), frequently dated at $66.4 \mathrm{Ma}$ (Berggren et al., 1985). Compared to the Deccan Traps which were erupted over a short interval $(<2 \mathrm{Ma}$; Courtillot et al., 1988; R.A. Duncan and Pyle, 1988 ), the Malagasy volcanism was of noticeably longer duration, suggesting the slow migration of the Malagasy plate over the Marion-Prince Edward hot spot. 


\section{Acknowledgements}

The study was supported by the Natural Sciences and Engineering Research Council of Canada (operating grant A3782) and Centre Géologique et Géophysique of Montpellier. We thank Dr. A.W. Hofmann for helpful comments.

\section{References}

Battistini, R., 1959. La structure du Massif de l'Androy (Madagascar). Bull. Soc. Géol. Fr., 7: 187-191.

Beane, J.E., Hooper, P.R. and Subbarao, K.V., 1988. Petrogenesis of the Kalsubai and Lonavala subgroups, Deccan basalt group, India. Int. Conf. on Geochemical Evolution of the Continental Crust, Abstr., Pocos de Caldas, pp. 48-53.

Bellieni, G., Comin-Chiaramonti, P., Marques, L.S., Melfi, A.J., Piccirillo, E.M., Nardi, A.J.R. and Roisenberg, A., 1984. High- and iow- $\mathrm{TiO}_{2}$ flood basalts from the Paraná plateau (Brazil): Petrology and geochemical aspects bearing on their mantle origin. Neues Jahrb. Mineral, Abh., 150: 273-306.

Berggrens, W.A., Kent, D.V., Flynn, J.J. and van Couvering. J.A., 1985. Cenozoic geochronology. Geol. Soc. Am. Bull., 96: 1407-1418.

Besairie. H. and Collignon, M., 1972. Géologie de Madagascar: Les terrains sédimentaires. Ann. Géol. Madagascar, No. 35, $105 \mathrm{pp}$.

Boast, J. and Nairn, A.E.M., 1982. An outline of the geology of Madagascar. In: A.E.M. Nairn and F.G. Stehli (Editors). The Ocean Basins and Margins, Vol. 6. Plenum, New York, N.Y., pp. 649-696.

Cantagrel, J.M. and Baubron, J.C., 1983. Chronologie des éruptions dans le massif volcanique du Mont Doré -Méthode K-Ar. Géol. Fr. BRGM (Bur. Rech. Géol. Min. ), 1: 123-142.

Clague, D.A. and Frey, F.A., 1982. Petrology and trace element geochemistry of the Honolulu volcanics, Oahu: implication for the oceanic mantle below Hawaii. J. Petrol., 23: 447-504.

Courtillot, V., Besse, J., Vandamme, D., Montigny, R., Jaeger, J.J. and Cappetta, H., 1986. Deccan flood basalts at the Cretaceous/Tertiary boundary? Earth Planet. Sci. Lett., 80:361-374.

Courtillot, V., Feraud, G., Maluski, H., Vandamme, D., Moreau, M.G. and Besse, J., 1988. Deccan flood basalts and the Cretaceous/Tertiary boundary. Nature (London), 333: 843-846.

Cox, K.G., 1988a. The Karoo Province. In: J.D. Macdougall (Editor), Continental Flood Basalts. Kluwer, Dordrecht, pp. 239-271.

Cox. K.G., 1988b. Numerical modelling of a randomized
RTF magma chamber: a comparison with continental flood basalt sequences. J. Petrol., 29: 681-697.

Cox, K.G. and Hawkesworth, C.J., 1984. Relative contribution of crust and mantle to flood basalt magmatism, Mahabaleshwar, Deccan Traps. Philos. Trans. R. Soc. London, Ser. A, 310: 627-641.

Cox, K.G. and Hawkesworth, C.J., 1985. Geochemical stratigraphy of the Deccan Traps at Mahabaleshwar, Western Ghats, India, with implications for open system magmatic processes. J. Petrol., 26: 355-388.

Dautria, J.M., Dostal, J., Dupuy, C. and Liotard, J.M., 1988. Geochemistry and petrogenesis of alkali basalts from Tahalra (Hoggar, Northwest Africa). Chem. Geol., 69: 17-35.

Dickin, A.P., Fallick, A.E., Halliday, A.N., Macintyre, R.M. and Stephens, W.E., 1986. An isotopic and geochronological investigation of the younger igneous rocks of the Seychelles microcontinent. Earth Planet. Sci. Lett., 81: 46-56.

Dostal, J., Baragar, W.R.A. and Dupuy, C., 1986. Petrogenesis of the Natkusiak continental basalts, Victoria Island, Northwest Territories, Canada. Can. J. Earth Sci., 23: 622-632.

Dostal, J., Dupuy, C., Zhai, M. and Zhi, X., 1988. Geochemistry and origin of Pliocene alkali basaltic lavas from Anhui-Jiangsu, Eastern China. Geochem. J., 22: 165-176.

Duncan, A.R., Erlank, A.J. and Marsh, J.S., 1984. Regional geochemistry of the Karoo igneous province. Geol. Soc. S. Afr., Spec. Publ., 13: 355-388.

Duncan, A.R., Marsh, J.S., Milner, S.C. and Erlank, A.J., 1988. Distribution and petrogenesis of the basic rocks of the Etendeka Formation of northwestern Namibia. Int. Conf. on Geochemical Evolution of the Continental Crust, Abstr., Pocos de Caldas, pp. 10-19.

Duncan, R.A., 1981. Hotspots in Southern Oceans - an absolute frame of reference for motion of the Gondwana continents. Tectonophysics, 74: 29-42.

Duncan, R.A. and Pyle, D.G., 1988. Rapid eruption of the Deccan flood basalts at the Cretaceous/Tertiary boundary. Nature (London), 333: 841-843.

Dupuy, C. and Dostal, J., 1984. Trace element geochemistry of some continental tholeiites. Earth Planet. Sci. Lett., 67: 61-69.

Erlank, A.J., 1984. Petrogenesis of the volcanic rocks of the Karoo province. Geol. Soc. S. Afr., Spec. Publ. No. 13, 395 pp.

Erlank, A.J., Marsh, J.S., Duncan, A.R., Miller, R.M., Hawkesworth, C.J., Betton, P.J. and Rox, D.C., 1984. Geochemistry and petrogenesis of the Etendeka volcanic rocks from SWA/Namibia. Geol. Soc. S. Afr., Spec. Publ., 13: 195-245.

Erlank, A.J., Duncan, A.R., Marsh, J.S., Sweeney, R.J., Hawkesworth, C.J., Milner, S.C., Miller, R. and Rogers, N.W., 1988. A laterally extensive geochemical discontinuity in the subcontinental Gondwana litho- 
sphere. Int. Conf. on Geochemical Evolution of the Continental Crust, Abstr., Pocos de Caldas, pp. 1-10.

Feigenson, M.D., Hofmann, A.W. and Spera, F.J., 1983. Case studies on the origin of basalt, II. The transition from tholeiitic to alkalic volcanism on Kohala Volcano, Hawaii. Contrib. Mineral. Petrol., 84: 390-405.

Gladney, E.S. and Roelandts, 1., 1988. 1987 Compilation of elemental concentration data for USGS BHVO- $I$, MAG-1, QLO-1. RGM-1, SCO-1, SDC-1, SGR-1 and STM-1. Geostand. Nesl., 12: 253-362.

Haq, B.U. and van Eysinga, F.W.B., 1987. Geological Time Table. Elsevier, Amsterdam (wall-chart).

Hartnady, C.J.H. and Le Roex, A.P., 1985. Southern Ocean hotspot tracks and the Cenozoic absolute motion of the African, Antarctic and South American plates. Erath Planet. Sci. Lett., 75: 245-257.

Jochum, K.P., Seufert, H.M., Spettel, B. and Palme, H., 1986. The solar-system abundances of $\mathrm{Nb}_{1} \mathrm{Ta}$ and $\mathrm{Y}_{1}$ and the relative abundances of refractory lithophile elements in differentiated planetary bodies. Geochim. Cosmochim. Acta, 50: 1173-1183.

Kay, R.W. and Gast, P.W., 1973. The rare earth content and the origin of alkali-rich basalts. J. Geol., $81: 653-$ 682.

Le Rocx, A.P., Dick, H.J.B., Erlank, A.J., Reid, A.M.. Frey, F.A. and Hart, S.R., 1983. Geochemistry, mineralogy and petrogenesis of lavas erupted along the Southwest Indian Ridge between the Bouvet triple junction and 11 East. J. Petrol., 24: 267-318.

Le Rocx, A.P., Dick, H.J.B., Reid, A.M., Frey, F.A., Erlank, A.J. and Hart, S.R., 1985. Petrology and geochemistry of basalts from the American-Antarctic Ridge, Southern Ocean: implications for the westward influence of the Bouvet mantle plume. Contrib. Mineral. Petrol., 90: 367-380.

Le Roex, A.P., Dick, H.J.B. and Fisher, R.L., 1989. Petrology and geochemistry of MORB from $25^{\circ} \mathrm{E}$ to $46^{\circ} \mathrm{E}$ along the Southwest Indian Ridge: Evidence for contrasting styles of mantle enrichment. J. Petrol., 30: 947 986.

Lightfoot. P. and Hawkesworth, C., 1988. Origin of Deccan Trap lavas: evidence from combined trace element and Sr-, Nd- and Pb-isotope studies. Earth Planet. Sci. Lett., 91: 89-104.

Mahoney, J.J., Macdougall, J.D., Lugmair, G.W., Murali, A.V.. Sankar Das, M. and Gopalan, K., 1982. Origin of the Deccan Trap flows at Mahabaleshwar inferred from $\mathrm{Nd}$ and $\mathrm{Sr}$ isotopic and chemical evidence. Earth Planet. Sci. Lett., 60: 47-60.

Mahoney, J.J., Macdougall, J.D., Lugmair, G.W., Gopalan, K. and Krishnamurthy, P., 1985. Origin of contemporaneous tholeiitic and $\mathrm{K}$-rich alkali lavas: a case study from the Northern Deccan Plateau, India. Earth Planet. Sci. Lett., 72: 39-53.

Mantovani, M.S.M., Marques, L.S., De Sousa, M.A., Civetta, L., Atalla. L. and Innocenti, F., 1985. Trace element and strontium isotope constraints on the origin and evolution of Paraná continental flood basalts of Santa Catarina State (southern Brazil). J. Petrol.. 26: $187-209$.

Marques, L.S., Piccirillo, E.M., Melfi. A.J., CominChiaramonti, P. and Bellieni, G., 1988. Geochemistry and REE distribution of flood basalt-rhyolite suites from the Paraná basin, Brazil. Int. Conf. on Geochemical Evolution of the Continental Crust, Abstr., Pocos de Caldas, pp. 70-79.

Marsh, J.S., 1987. Basalt geochemistry and tectonic discrimination within continental flood basalt provinces. J. Volcanol. Geotherm. Res., 32: 35-49.

Masuda, A., Nakamura, N. and Tanaka, T., 1973. Fine structures of mutually normalized rare-earth patterns of chondrites. Geochim. Cosmochim. Acta, 37: 239248.

McDonough, W.F., McCulloch, M.T. and Sun, S.S., 1985. Isotopic and geochemical systematics in Tertiary-Recent basalts from southeastern Australia and implications for the evolution of the sub-continental lithosphere. Geochim. Cosmochim. Acta, 49: 2051-2067.

Newsom. H.E., White, W.M., Jochum, K.P. and Hofmann, A.W.. 1986. Siderophile and chalcophile element abundances in oceanic basalts, $\mathrm{Pb}$ isotope evolution and growth of the Earth's core. Earth Planet. Sci. Lett., 80: 299-313.

Nicollet, C., 1984. Le volcanisme dans le Sud-Ouest de Madagascar. J. Afr. Earth Sci.. 2: 383-388.

Norton, I.O. and Sclater, J.G., 1979. A model for the evoIution of the Indian Ocean and the breakup of Gondwanaland. J. Geophys. Res., 84: 6803-6830.

O'Hara, M.J., 1977. Geochemical evolution during fractional crystallization of a periodically refilled magma chamber. Nature (London), 266: 503-507.

Peate, D.W., Hawkesworth, C.J. and Mantovani, M.S.M., 1988. Lithospheric to asthenospheric transition within the coastal margin CFB of the Parana province. Int. Conf. on Geochemical Evolution of the Continental Crust. Abstr., Pocos de Caldas. pp. 80-83.

Piccirillo, E.M., Civetta, L.. Petrini, R., Longinelli, A., Bellieni, G., Comin-Chiaramonti, P., Marques, L.S. and Melfi, A.J., 1989. Regional variations within the Paraná flood basalts (southern Brazil): Evidence for subcontinental mantle heterogeneity and crustal contamination. Chem. Geol., 75: 103-122.

Rechenmann, L., 1982. Gravimetrie de Madagascar Interprétation et relations avec la géologie. ORSTOM (Off. Rech. Sci. Tech. Outre-mer) Géophys., 18: 3128.

Segoufin, J. and Patriat, P., 1981. Réconstructions de l'Océan Indien occidental pour les époques des anomalies M21, M2 et 34 - Paléoposition de Madagascar. Bull. Soc. Géol. Fr., 23: 603-607.

Shervais, J.W., 1982. Ti-V plots and the petrogenesis of modern and ophiolitic lavas. Earth Planet. Sci. Let1., 59: $101-118$. 
Sun, S.S. and McDonough, W.F., 1989. Chemical and isotopic systematics of oceanic basalts: implications for mantle composition and processes. In: A.D. Saunders and M.J. Norry (Editors), Magmatism in Ocean Basins. Shiva, Nantwich, pp. 313-345.

Taylor, S.R. and McLennan, S.M., 1985. The Continental Crust: Its Composition and Evolution. Blackwell, Oxford. $312 \mathrm{pp}$.

Thompson, R.N., Dickin, A.P., Gibson, I.L. and Morrison, M.A., 1982. Elemental fingerprints of isotopic contamination of Hebridean Paleocene mantle derived magmas by Archean sial. Contrib. Mineral. Petrol., 79: 159-168.
Weaver, B.L., Wood, D.A., Tarney, J. and Joron, J.S.. 1987. Geochemistry of ocean island basalts from the South Atlantic: Ascension, Bouvet, St. Helena, Gough and Tristan da Cunha. In: J.G. Fitton and B.G.J. Upton (Editors), Alkaline Igneous Rocks. Geol. Soc. London, Spec. Publ. No. 30, pp. 253-267.

Wedepohl, K.H., 1985. Origin of the Tertiary basaltic volcanism in Hessian depression. Contrib. Mineral. Petrol., 89: 122-143.

White, R. and McKenzie, D., 1989. Magmatism at rift zones: the generation of volcanic continental margins and flood basalts. J. Geophys. Res., 94 (B6): 76857729 . 